\title{
Supplementary Feeding Development of Koya Powder Based on Rebon Shrimp (Mysis Relicta) towards Changes in Blood Biochemistry of Pregnant Women as Risk Factor of Linier Growth Disturbance (Stunting)
}

\author{
Vera Iriani Abdullah ${ }^{1}$, Mariana Isir ${ }^{1}$, Ariani Pongoh ${ }^{1}$, Adriana Egam ${ }^{1}$, Anwar Mallongi \\ ${ }^{1}$ Lecturers of Poltekkes Kemenkes Sorong, ${ }^{2}$ Professor of Environmental Health Department, \\ Faculty of Public Health, Hasanuddin University, Makassar
}

\begin{abstract}
Indonesia is ranked 5th in the world and 3rd in Southeast Asia with the highest number of stunted children under five. West Papua Province in 2018 is included in 18 provinces with a high prevalence of around $30 \%-<40 \%$. Stunting is one of the nutritional problems that occur from the pre-conception period, and will continue until pregnancy which can affect the baby being born. One of the efforts that can be done by giving rebon shrimp, its content which is rich in micronutrients can be an alternative food choice for improving blood biochemistry of pregnant women. The purpose of this study is to analyze the differences in blood biochemical levels of pregnant women (serum protein, serum albumin and hemoglobin levels) before and after consuming the supplementary feeding of Koya Powder made from Rebon Shrimp. This study used a quasi-experimental method with a group design post-test control approach. The total sample size is 15 respondents per group, using the incidental technique. The intervention group was given koya powder as much as 100 grams/day for 7 days, while the control was given education on nutritious foods and eating according to the daily pattern. The research was conducted in the work area of the West Sorong Health Center and Malawili Public Health Center, data collection was carried out from 31 August 2020 to 06 October 2020, using an observation sheet. Data analysis used the Mann-Whitney test, if the data were not normally distributed. If the data were not normally distributed, use the free sample t 2 test. The results of the study were significant differences between the control group and the intervention group with a $\mathrm{P}$ value of $0.000<0.05$. Conclusion "There is an Effect of Consumption of Supplementary Feeding Koya Powder Made from Rebon Shrimp (Mysis Relicta) on Changes in Serum Protein, Serum Albumin and Hemoglobin Levels for Pregnant Women as Risk Factors for Stunting."
\end{abstract}

Keywords: Rebon Shrimp, Blood Biochemical,Stunting and West Papua.

\section{Introduction}

Based on data from the World Health Organization (WHO), South East Asia Regional (SEAR), Indonesia is in the third highest position with an average of around $36.4 \%$ of children under five with stunting in 2005-2017. Riskesdas, ${ }^{1}$ For this reason, referring to the RPJMN (National Medium-Term Development Plan) target in 2019 , it is expected that the number of babies under two years of stunting in Indonesia can reach a figure below 28\%. Based on data from Riskesdas (Basic Health Research) in 2013, around 37.2\% (9 million) of children under five were stunted, so that Indonesia was ranked 5 th in the world. ${ }^{2}$
The latest Riskesdas in 2018 shows a decrease in the prevalence of children under five with very short and short criteria by $30.8 \%$, although there has been a decrease in cases but has not reached the expected target Riskesdas, ${ }^{1}$ West Papua Province in 2018 is included in 18 provinces with a high prevalence of around $30 \%$ $<40 \%$ of cases are short and very short with indicators of height according to age (Height/Age), where the very short category is $\mathrm{TB} / \mathrm{U}<-3 \mathrm{SD}$ and the short category Height/Age $\geq-3$ SD to $<-2$ SD. Priority for subscribing to stunting intervention is focused on 3 loci, namely Sorong City, South Sorong Regency and Tambraw ${ }^{2}$ 
Stunting is one of the nutritional problems experienced by children under five today, the results of an analysis of 217 national Demographic and Health surveys from 67 countries with $\geq 2$ surveys between 1993 and 2014, showed the average prevalence of stunting in 1993 was $53.7 \%$ in low-income countries and $48.2 \%$ in middle-income countries. Stunting occurs from the pre-conception period, the condition is lack of nutrition and anemia is one of the triggers. This condition will get worse when entering conception because of insufficient nutritional intake to meet needs. Mothers with infection and/or chronic disease directly contribute to micronutrient deficiencies that inhibit nutrient absorption ${ }^{3}$, .

During pregnancy, increased nutritional intake is required, micronutrient deficiency which less exacerbates this period. Evidence suggests that repeated pregnancies with short intervals between pregnancies contribute to the micronutrient status of pregnant women. Micronutrient deficiency is associated with a number of adverse outcomes for both mother and baby ${ }^{4}$. The impact of lack of nutrition during pregnancy will affect the level of intelligence, and are more susceptible to disease. Efforts to prevent and reduce stunting by addressing these factors use a life-cycle approach ${ }^{5}$. One of them is providing optimal nutritional intake during pregnancy by Ministry of Health of the Republic of Indonesia.

WHO recommends iron folic acid supplementation of 30-60 mg of elemental iron and $400 \mu \mathrm{g}$ of folic acid per day ${ }^{4}$. Rebon shrimp is included in the type of shrimp, according to the Ministry of Health in 2005: 9 quoted in Syarif et al., that every 100 grams of dried rebon shrimp contains $295 \mathrm{cal}$ calories, $62.4 \mathrm{~g}$ protein, $2.3 \mathrm{~g}$ fat, 1.8 grams of carbohydrates, $1209 \mathrm{mg}$ of calcium, $1225 \mathrm{mg}$ of phosphorus, $6.3 \mathrm{mg}$ of iron, $210 \mathrm{mg}$ of vitamin A, $0.14 \mathrm{mg}$ of vitamin $\mathrm{B} 1,20.7 \mathrm{~g}$ of water. ${ }^{6}$.

The high number of cases of linear disorders in infants and the importance of addressing this problem, the researchers want to explore the potential of Papua's marine resources, to be used as an alternative food choice through research "Supplementary Feeding Development of Koya Powder Based on Rebon Shrimp (Mysis Relicta) Towards Changes In Blood Biochemistry Of Pregnant Women As Risk Factor Of Linier Growth Disturbance (Stunting)"with the hope that the results of this study can be useful for the Papuan people, to raise local food wisdom.

\section{Materials and Method}

This study used a quasi experimental design, with a pretest-posttest control group design. Before and after the intervention, a pregnant woman's blood biochemistry will be examined (Serum Protein, serum albumin and hemoglobin). This research has passed the ethics test by the Ethics Team of the Health Polytechnic of the Ministry of Health in Sorong and has obtained a research permit. The sample in this study were 30 pregnant women, using the Cluster Random Sampling technique ${ }^{7}$. Samples were divided into 2 groups with the same number, the intervention group was given koya powder as much as 100 grams/day for 7 days and the control group was given health education on nutritious food by consuming a daily diet, for SF tablets still consumed in both groups. Rebon Koya powder is made by the research team with a composition of $20 \%$ shrimp crackers and $80 \%$ rebon shrimp. The research instrument used an observation sheet to assess changes in serum protein levels which were categorized as Low if $<6.40 \mathrm{~g} / \mathrm{dl}$ and Normal if Normal $>6.40 \mathrm{~g} / \mathrm{dl}$. To assess changes in serum albumin levels, it is categorized as Low if $<3.4 \mathrm{mg} / \mathrm{dl}$ and Normal if $>3.4 \mathrm{mg} / \mathrm{dl}$. Meanwhile, to assess changes in serum hemoglobin levels in the category Low if $<10.5 \mathrm{~g} / \mathrm{dl}$ and Normal if $>10.5 \mathrm{~g} / \mathrm{dl}$. Blood Biochemistry before and after intervention in both the intervention and control groups used a paired $\mathrm{T}$ test if the data were normally distributed and used the Wilcoxon test if not normally distributed. Meanwhile, to measure differences in Blood Biochemistry before and after intervention between the intervention and control groups using the Mannwhitneytest, if the data are not normally distributed. If the data are not normally distributed using the free sample $\mathrm{t} 2$ test, because the data are not paired. 


\section{Results and Discussion}

\section{Univariate analysis}

a. Characteristics of Research Subjects: Respondent characteristics include age, religion, occupation, parity and gestational age. For more details, see the description below:

Table 1. Characteristics of Research Subjects in the Intervention Group and Control Group

\begin{tabular}{|c|c|c|c|c|c|}
\hline \multirow{3}{*}{ No. } & \multirow{3}{*}{ Variable } & \multicolumn{4}{|c|}{ Group } \\
\hline & & \multicolumn{2}{|c|}{ Intervention $(n=15)$} & \multicolumn{2}{|c|}{ Control (n=15) } \\
\hline & & $\mathbf{N}$ & $\%$ & $\mathbf{N}$ & $\%$ \\
\hline \multirow{5}{*}{1.} & \multicolumn{5}{|l|}{ Age } \\
\hline & $<20$ & 1 & 6,6 & 1 & 6,6 \\
\hline & $20-35$ & 14 & 93,3 & 13 & 86,6 \\
\hline & $>35$ & 0 & 0 & 1 & 6,6 \\
\hline & Total & 15 & 100 & 15 & 100 \\
\hline \multirow{5}{*}{2.} & \multicolumn{5}{|l|}{ Religion } \\
\hline & Islam & 15 & 100 & 11 & 73,3 \\
\hline & Protestant & 0 & 0 & 3 & 20 \\
\hline & Catholic & 0 & 0 & 1 & 6,6 \\
\hline & Total & 15 & 100 & 12 & 100 \\
\hline \multirow{4}{*}{3.} & \multicolumn{5}{|l|}{ Occupation } \\
\hline & Housewife & 15 & 100 & 15 & 100 \\
\hline & Non Housewife & 0 & 0 & 0 & 0 \\
\hline & Total & 15 & 100 & 15 & 100 \\
\hline \multirow{5}{*}{4.} & \multicolumn{5}{|l|}{ Parity } \\
\hline & 1 (Primigravida) & 3 & 20 & 5 & 33,3 \\
\hline & 2-5 (Multigravida) & 12 & 80 & 10 & 66,6 \\
\hline & $>5$ (Grandemultipara) & 0 & 0 & 0 & 0 \\
\hline & Total & 15 & 100 & 15 & 100 \\
\hline \multirow{5}{*}{5} & \multicolumn{5}{|l|}{ Gestational Age } \\
\hline & 1-13 weeks (TM I) & 3 & 20 & 1 & 6,6 \\
\hline & $14-26$ weeks (TM 2) & 4 & 26,6 & 7 & 46,6 \\
\hline & $27-40$ weeks (TM 3 ) & 8 & 53,3 & 7 & 46,6 \\
\hline & Total & 15 & 100 & 15 & 100 \\
\hline
\end{tabular}

Table 1 shows that the characteristics of respondents based on age in the intervention and control group were mostly at the age of 20-35 years, in the intervention group as many as 14 respondents $(93.3 \%)$ while in the control group as many as 13 respondents $(86.6 \%)$. For the characteristics of respondents based on religion, both the intervention and control groups were mostly Muslim, in the intervention group there were 15 respondents $(100 \%)$ while the control group was 11 respondents
(73.3\%). \%) Housewife. Characteristics of Respondents based on parity in the intervention and control groups mostly in the 2-5 children or multigravida group. The intervention group was 12 respondents $(80 \%)$, while in the control group there were 10 respondents $(66.6 \%)$. Characteristics of respondents based on gestational age in the intervention group were mostly in the gestational age group in trimester 2 ranging from 27-40 weeks of gestation as many as 8 respondents $(53.3 \%)$. Whereas 
in the control group, most of them were in the 2nd and $3 \mathrm{rd}$ trimesters of pregnancy, each of which were 7 respondents $(46.6 \%)$.

b. Like or Organoleptic Test: To assess the texture, taste, color and aroma between formula $\mathrm{A}$ and formula B. More details can be seen in Table 2 below:

Table 2. Like Or Organoleptic Test Results

\begin{tabular}{|l|c|c|}
\hline Type of Treatment & Preferred Level & Category \\
\hline Formula A & \multicolumn{2}{|l|}{} \\
\hline Texture & 4 & Like \\
\hline Taste & 5 & Very Like \\
\hline Color & 4 & Like \\
\hline Aroma & 4 & Like \\
\hline Formula B & 2 & Dislike \\
\hline Texture & 3 & Neutral \\
\hline Taste & 2 & Dislike \\
\hline Color & 2 & Dislike \\
\hline Aroma
\end{tabular}

In the preference test of 10 panelists, it shows that the respondent prefers the texture of Formula A, for the taste the Respondents really like formulation A. As for the color and aroma of the Respondents like formulation A. Thus, the formula used for this study is Formula A. c. Compliance Test: To measure Respondents' compliance to consume Koya Shrimp Rebon Powder per day. More details can be seen in table 3 below:

\section{Table 3 Compliance Test Consuming Rebon Shrimp} Koya Powder

\begin{tabular}{|c|l|c|c|}
\hline No. & Compliance Level & Frequency (n) & $\begin{array}{c}\text { Percentage } \\
\text { (\%) }\end{array}$ \\
\hline 1 & Low (25gr/day) & 0 & 0 \\
\hline 2 & Medium(50gr/day) & 1 & 6,6 \\
\hline 3 & High(100 gr/day) & 14 & 93,3 \\
\hline \multicolumn{2}{|c|}{ Total } & $\mathbf{1 5}$ & $\mathbf{1 0 0 \%}$ \\
\hline
\end{tabular}

Based on Table 3 regarding the compliance of Respondents consuming Koya Powder for 1 week with a frequency of $25 \times$ 4/day (Total $100 \mathrm{gr} /$ day), it shows that as many as 14 respondents $(93.3 \%)$ have a high level of compliance while 1 respondent $(6.6 \%)$ ) have a moderate level of adherence, this is because the mother has entered the final week of preparation for delivery so that the desire to eat has decreased.

d. Blood Biochemical Levels of Pregnant Women Before And After Intervention: Measuring the average blood biochemistry includes Serum Protein, Serum Albumin and Hemoglobin before and after the intervention for 7 days. More details can be seen in table 4 below:

Table 4. Mean of Blood Biochemical Levels of Pregnant Women before And After Intervention

\begin{tabular}{|l|c|c|c|c|c|c|}
\hline \multirow{2}{*}{ Group } & \multicolumn{7}{|c|}{ Mean \pm Std. Deviation } \\
\cline { 2 - 8 } & Hb & Protein & Albumin & Hb & Protein & Albumin \\
\cline { 2 - 8 } & $10.453 \pm 1.8189$ & $5.867 \pm 0.5948$ & $3.527 \pm 0.4183$ & $11,107 \pm 1,7015$ & $6.493 \pm 0.8388$ & $3,753 \pm 0,4642$ \\
\hline Intervention & $11.513 \pm 1.1575$ & $7.113 \pm 1.1904$ & $3.580 \pm 0.3075$ & $11.073 \pm 1.1094$ & $6.427 \pm 0.9677$ & $3.600 \pm 0.4175$ \\
\hline Control & &
\end{tabular}

Table 4 above shows that the mean results of changes in the blood biochemical content of pregnant women in the control group were smaller than the intervention group. After that, the univariate test will be carried out with the Paired Samples Test. The normality test will be carried out first, which aims to determine how the distribution of data is needed and determine the data that has been collected is normally distributed or taken from the normal population. The normality test was carried out using the Shapiro-Wilk method because the sample data in each group was less than 50 samples. If $p>0.05$ is obtained, the data is normally distributed. The results of the normality test can be seen in Table 5 below: 
Table 5. Univariate Normality Test Results Using Shapiro Wilk

\begin{tabular}{|l|l|c|l|}
\hline \multicolumn{1}{|c|}{ Data } & Gis & Details \\
\hline \multirow{5}{*}{} & Intervention Group HB Before & 0,323 & The data is normally distributed \\
\cline { 2 - 4 } & Intervention Group HB After & 0,155 & The data is normally distributed \\
\cline { 2 - 4 } & Intervention Group of Serum albumin Before & 0,022 & The data isnot normally distributed \\
\cline { 2 - 4 } & Intervention Group of Serum albumin After & 0,007 & The data isnot normally distributed \\
\cline { 2 - 5 } & Intervention Group Protein Serum Before & 0,314 & The data is normally distributed \\
\cline { 2 - 5 } & Intervention Group Protein Serum After & 0,230 & The data is normally distributed \\
\cline { 2 - 5 } & Group Control HB Before & 0,004 & The data isnot normally distributed \\
\cline { 2 - 5 } & Group Control HB After & 0,006 & The data isnot normally distributed \\
\cline { 2 - 5 } & Group Control Protein Serum Before & 0,048 & The data is not normally distributed \\
\cline { 2 - 5 } & Group Control Protein Serum After & 0,366 & The data is normally distributed \\
\cline { 2 - 4 } & Group Control Albumin Serum Before & 0,142 & The data is normally distributed \\
\cline { 2 - 4 } & Group Control Albumin Serum After & The data is normally distributed \\
\hline
\end{tabular}

From table 5 above, it is found that some data are normally distributed and not. After the normality test, the Paired Samples Test will be carried out on the HB sample of koya powder, koya protein powder and control albumin. The Paired Samples Test is a two-time difference test for data that is normally distributed and is used to see changes in giving Supplementary Feeding of koya powder before and after being treated. For the other sample, the Wilcoxon test was carried out because the data distribution was not normally distributed. If $\mathrm{p}$ $<0.05$ then there is a significant difference.

Table 6. Univariate Test Results Using Paired Samples Test and Wilcoxon

\begin{tabular}{|c|c|c|c|}
\hline \multicolumn{2}{|r|}{ Data } & Gis & Details \\
\hline \multirow{6}{*}{$\begin{array}{l}\text { Paired Samples } \\
\text { Test and } \\
\text { Wilcoxon }\end{array}$} & HB Before And After Intervention Group & 0,002 & There is a significant difference \\
\hline & $\begin{array}{l}\text { Albumin Serum Before And After Intervention } \\
\text { Group }\end{array}$ & 0,003 & There is a significant difference \\
\hline & $\begin{array}{l}\text { Protein Serum Albumin Serum Before And After } \\
\text { Intervention Group }\end{array}$ & 0,003 & There is a significant difference \\
\hline & HB Before And After Control Group & 0,002 & There is a significant difference \\
\hline & Albumin Serum Before and After Control Group & 0,767 & There is no significant difference \\
\hline & $\begin{array}{l}\text { Protein Serum Albumin Serum Before and After } \\
\text { Control Group }\end{array}$ & 0,003 & There is a significant difference \\
\hline
\end{tabular}

The results of the Paired Samples Test and Wilcoxon test in Table 6 above, for the whole sample experienced a significant difference, only control albumin is not. To prove the difference in the effectiveness of Supplementary Feeding of koya powder on changes in blood biochemistry of pregnant women, a bivariate test was carried out using the Independent Samples Test. Data normality testing is required to meet the requirements of the Independent Samples Test.
2. Bivariate Analysis: To see the relationship between the dependent variable and the independent variable. So to measure the differences in blood biochemistry of pregnant women, before and after intervention between the intervention and control groups used the Mann-Whitney test, if the data were not normally distributed. If the data are not normally distributed using the free sample 2 test. 
Table 7. Bivariate Normality Test Results Using Kolmogorov Smirnov Z

\begin{tabular}{|c|c|c|c|}
\hline \multicolumn{2}{|r|}{ Group } & Gis & Details \\
\hline \multirow{2}{*}{$\begin{array}{l}\text { Test of } \\
\text { normality }\end{array}$} & Intervention & 0.000 & Data isnot normally distributed \\
\hline & Control & 0.000 & Data isnot normally distributed \\
\hline
\end{tabular}

From Table 7 above, it is found that the data are not normally distributed. After that, the homogeneity test was carried out with the Levene test to see whether the data variance was homogeneous or not. The results of the homogeneity test of the data variance are not homogeneous. The data are not normally distributed and are not homogeneous so that the Independent Sample Test can not be done. The results of the homogeneity and normality test meet the requirements of the Mann Whitnney test.

It is found that the data variance is not homogeneous, which means that all the requirements are met. After that, the Mann Whitnney test is carried out with the results in Table 9, the results show that there is a significant difference. The conclusion of the null hypothesis is rejected thus "There is an Effect of Consuming Supplementary Feeding of Koya Powder Made from Rebon Shrimp. (Mysis Relicta) Towards Changes in Serum Protein, Serum Albumin, and Hemoglobin Levels for Pregnant Women as Risk Factors for Stunting.

\section{Discussion}

Characteristics in the age group of respondents, both the intervention and control groups, are mostly at the age of 20-35 years, this is a safe gestational age and delivery because at this age the mother is physically and mentally ready to face pregnancy and childbirth besides that the risk of anemia is very low. A study conducted by Zahidatul 8 shows that pregnant women aged $<20$ years have a 2,250 times greater risk of anemia and $>35$ years of age have a risk of experiencing anemia 5.885 times greater than those of 20-35 years. However, this is not in line with the data obtained by researchers where there are still respondents who have low hemoglobin levels $<10.5 \mathrm{~g} / \mathrm{dl}$, even though the percentage is below $50 \%$.

Respondents in both groups are $100 \%$ unemployed, meaning that mothers carry out their daily obligations as housewives, the group of mothers who do not work is a group that is prone to suffering from anemia, where the data shows that mothers who do not work have a 1.990 greater chance of experiencing anemia compared to working pregnant women. Mothers who do not work have to do hard work during pregnancy to meet their needs. In addition, this group tends to have a lower socioeconomic status so that nutritional needs are not fulfilled ${ }^{8}$.

Parity in the intervention and control groups mostly at parity of 2-5 children, the number of children greatly affects the nutritional status of children under five. Toddlers from families with a large number of household members are 1.34 times more likely to experience stunting compared to toddlers from families with sufficient household members ${ }^{9}$. Mothers who had many children under five had a 3.25 times greater risk of stunting than respondents who had mothers with little parity lack of time in sharing attention to children, the limited food consumed by children is a trigger factor ${ }^{10}$.

There is a significant difference between mothers who were given rebon shrimp koya powder and mothers who were only given education to eat according to their daily diet. Giving rebon shrimp koya powder can meet $70 \mathrm{KKal}$, with a composition of $41 \mathrm{mg}$ of Calcium (Ca), $265 \mathrm{mg}$ of protein, $21.4 \mathrm{mg}$ of Fe, $0.06 \mathrm{mg}$ of Vitamin B1 and 21.6 grams of water. Protein content in the body functions as a means of transporting iron. Consumption of foods high in protein can increase hemoglobin levels. This is in line with research conducted in Sorong Regency, 2019, showing that women of childbearing age who consume shellfish biscuits can significantly increase their hemoglobin levels because shellfish are rich in protein ${ }^{11}$.

While the content of Calcium $(\mathrm{Ca})$ affects genetic programs that determine height. If calcium intake is reduced it will cause low blood calcium levels and can interfere with the genetic high process. Calcium (Ca), phosphorus (Pi), and Magnesium $(\mathrm{Mg})$ are the main minerals in fetal bone mineralization. Low levels of calcium in maternal serum can cause low serum Ca levels in the fetus ${ }^{12}$. 
Serum albumin levels are essential during pregnancy for good delivery outcomes, Department of Obstetrics and Gynecology at Rajshahi Medical College Hospital, Rajshahi, Bangladesh from January 2013 to December 2014 for a period of two (2) years. Serum albumin level is not a predictor of the development of preeclampsia in early stage pregnant women. A study conducted at Gambella Hospital, Southwest Ethiopia from January to March 2016, involving 246 pregnant women showed that low serum albumin levels and anemia were closely associated with zinc deficiency, as a result of lack of consumption. foods from animal sources and a variety of side dishes when eating in pregnant women. This has an adverse effect on both the mother and the fetus, which can lead to increased morbidity ${ }^{13,14}$

Pregnant women who are deficient in zinc can cause gestational hypertension, defects in fetal nerves, premature rupture of membranes, low birth weight, poor neurodevelopmental behavior, cognitive impairment, intrauterine growth retardation, impaired glucose tolerance, congenital malformations, stillbirth, premature labor, postpartum hemorrhage, prolonged labor, inadequate uterine contractions, abnormalities in gene replication, delayed immune system development leading to increased neonatal morbidity and mortality. Serum albumin acts as an antioxidant in the body, low albumin levels in pregnant women are closely associated with the incidence of gestational diabetes. Decreased albumin levels are due to malnutrition ${ }^{15-22}$.

Maternal nutritional status during pregnancy greatly affects the risk factors for stunting in children. Hardening of the bones begins approximately in the sixth week of embryonic development and continues until the end of pregnancy. However, an insufficient supply of nutrients in pregnant women impairs fetal growth. The results showed that maternal nutritional status during pregnancy was significantly associated with stunting in children (p-value: 0.000 ). The OR value is 13,222 , which means that children born to mothers with insufficient nutritional supply during pregnancy are 13,222 times more likely to suffer from stunting than children born to mothers with good nutrition supplies. ${ }^{23}$

Linear growth failure is the most common form of malnutrition globally. With an estimated 165 million children under 5 years of age affected, stunting has been identified as a top public health priority, and there are ambitious targets to reduce stunting prevalence by $40 \%$ between 2010 and 2025 . We view this condition as a 'stunting syndrome' in where several pathological changes characterized by decreased linear growth in early life are associated with increased morbidity and mortality, decreased physical capacity, neurological and economic development and an increased risk of metabolic disease into adulthood. tend to have neglected offspring, creating an intergenerational cycle of poverty and depletion of human resources that is difficult to break $^{12}$.

Deficiency of micronutrients is one of the triggers for stunting in addition to non-optimal breastfeeding and complementary feeding practices, as well as recurrent infections. In the antenatal period Fetal growth is regulated by a complex interaction of maternal nutritional status, endocrine and metabolic signals, and placental development. For this reason, prenatal micronutrients and provision of balanced energy and protein for mothers can reduce the incidence of stunting by $9 \%$ and $31 \%$. Daily iron supplementation during pregnancy reduces low birth weight by $20 \% .^{12}$

Stunting reflects poor nutrition and frequent infections can lead to poor cognitive, motor and socioeconomic development. Globally, one fifth of pregnant women develop iron deficiency anemia during pregnancy. A meta-analysis showed that anemia during the first or second trimester increases the risk of prematurity and low birth weight. The WHO recommends $60 \mathrm{mg}$ of iron daily during pregnancy, however, a randomized controlled trial in Bangladesh showed that supplementing iron with multiplemicronutrient intake had a slightly more effect on children's body length at birth, first, third and sixth month. Thus, the addition of micronutrients with iron tablets to pregnant women will have a more positive impact on linear disturbances in babies born.

\section{Conclusion}

1. The mean serum protein level before consuming the Supplementary Feeding of Rebon Shrimpbased Koya Powder in the Intervention Group was $5,867 \pm 0.5948$ and after it was $6,493 \pm 0.8388$. The mean serum albumin levels before consuming the Supplementary Feeding of Rebon ShrimpBased Koya Powder in the Intervention Group were $3.527 \pm 0.4183$ and after $3.753 \pm 0.4642$. The mean hemoglobin level before consuming the Supplementary Feeding of Rebon-based Koya Shrimp in the Intervention Group was $10,453 \pm$ 1,8189 and after $11,107 \pm 1,7015$. 
2. The mean serum protein level before the intervention in the control group was 7,113 $\pm 1,1904$ and after that was $6,427 \pm 0.9677$. The mean serum albumin level before intervention in the control group was $3.580 \pm 0.3075$ and after $3.600 \pm 0.4175$. The mean hemoglobin level before the intervention in the control group was $11,513 \pm 1.1575$ and after it was $11,073 \pm 1.1094$.

3. There were significant differences in serum protein levels before and after Consuming Supplementary Feeding of Rebon Shrimp-Based Koya Powder in the intervention group with a significant value of $\mathrm{P}$ $0.003<0.05$. There were significant differences in serum albumin levels before and after consuming the Supplementary Feeding of Rebon-based Koya Shrimp in the Intervention Group with a significant value of $\mathrm{P} 0.003<0.05$. There is a significant difference in hemoglobin levels before and after consuming the Supplementary Feeding of Rebon Shrimp-based Koya Powder in the intervention group with a significant value of $\mathrm{P} 0.002<0.05$

4. There was a significant difference in serum protein levels before and after the intervention in the control group with a significant value of P 0.003 $<0.05$. There was no significant difference in serum albumin levels before and after intervention in the control group with a significant value of P $0.767>$ 0.05 . There is a significant difference in hemoglobin levels before and after the intervention in the control group with a significant value of $\mathrm{P} 0.002<0.05$

5. There was a significant difference between the Control and Intervention Groups with a significant value of $\mathrm{P} 0.000<0.05$

Ethical Clearance: Taken from Poltekkes Kemenkes Sorongethical committee

Source of Funding: Poltekkes Kemenkes Sorong

\section{Conflict of Interest: Nil}

\section{References}

1. Riskesdas. Hasil Utama Riskesdas Tentang Prevalensi Diabetes Mellitus di Indonesia 2018', Hasil Utama Riskesdas Tentang Prevalensi Diabetes Melitus di Indonesia 2018, p. 8. doi: 1 Desember 2013.

2. TNP2TK (Tim Nasional Percepatan Penanggulangan Kemiskinan) 100 Kabupaten/Kota
Prioritas Untuk Intervensi Anak Kerdil (Stunting), 2010

Haider, B. A. et al. (2013). Anaemia, Prenatal Iron Use, And Risk Of Adverse Pregnancy Outcomes: Systematic Review And Meta-Analysis.BMJ (Online). doi: 10.1136/bmj.f3443.

3. Da Silva, I. C. M. et al.. Socioeconomic Inequalities Persist Despite Declining Stunting Prevalence In Low- And Middle-Income Countries', Journal of Nutrition, 148(2), pp. 254-258. doi: 10.1093/jn/ nxx050. 2018.

4. Keats, E. C., Imdad, A. and Bhutta, Z. A.. Effects Of Vitamin And Mineral Supplementation During Pregnancy On Maternal, Birth, Child Health And Development Outcomes In Low- And MiddleIncome Countries - The Campbell Collaboration. 2018. (November), pp. 1-33. Available at: Kementerian Kementrian Kesehatan Republik Indonesia. (2018). Buletin Stunting. Kementerian Kesehatan Republik Indonesia, 1, p. 2.

5. Branca, F. And Ferrari, M.. Impact Of Micronutrient Deficiencies On Growth: The Stunting Syndrome', Annals Of Nutrition And Metabolism, 2002; 46(SUPPL. 1), pp. 8-17. doi: 10.1159/000066397.

6. Syarif, W. et al.. Analisis Kualitas Sala Udang Rebon, Jurnal Teknologi Pertanian Andalas, 2017; 21(1), p. 45. doi: 10.25077/jtpa.21.1.45- 51.2017. wikimedia-button.

7. Mieke.H.Satari, F. F. W. Konsistensi Penelitian. Edisi Ke-1. Bandung. 2011

8. Zahidatul Rizkah and Trias Mahmudiono. Hubungan Antara Umur, Gravida, Dan Status Bekerja Terhadap Resiko Kurang Energi Kronis (KEK) Dan Anemia Pada Ibu Hamil', Amerta Nutrition, 2017; 1(2), pp. 72-79. doi: 10.20473/ amnt.v1.i2.2017.72-79

9. Apriasih, H.. Pengaruh Paritas Di Keluarga Terhadap Status Gizi Anak Balita Dalam Pencegahan Stunting, 2020; pp. 84-89.

10. Jihad, J., Ahmad, L. and ainurrafiq, A.. Analisis Determinan Kejadian Stunting Pada Balita Usia 12-24 Bulan Di Wilayah Kerja Puskesmas Puuwatu Kota Kendari Tahun 2016. Jurnal Ilmiah Mahasiswa Kesehatan Masyarakat Unsyiah, 2016; 1(3), p. 186502.

11. Abdullah, V. I. And Haumahu, C. Pengaruh Konsumsi Cookies Kerang Dara (Anadara Granosa) Terhadap Perubahan Kadar Haemoglobin Wanita 
Usia Subur, Journal Of Holistic Nursing Science, 2020; 7(2), Pp. 169-179. Doi: 10.31603/Nursing. V7i2.3126.

12. Prendergast, A. J. and Humphrey, J. H. The Stunting Syndrome In Developing Countries', Paediatrics And International Child Health, 2014; 34(4), pp. 250-265. doi: 10.1179/2046905514Y.0000000158.

13. Begum, T. et al.. Association Of Serum Albumin Level In Predicting Of Preeclampsia Among Pregnant Women In Dhaka City Of Bangladesh, Journal of Current and Advance Medical Research, 2019; 6(2), pp. 83-86. doi: 10.3329/jcamr. v6i2.42976.

14. https://manfaat.co.id/manfaat-udang-kering. Manfaat Udang Rebon Terhadap Kesehatan. Di Unduh Tanggal 20 Februari 2020

15. Kumar, P., Patel, S. and College, M.. International Journal Of Scientific Research Comparative Study Of Serum Albumin And Uric Acid In Gestational Diabetes Mellitus With Healthy PREGNANCY Dr . Hem Priya Dr . Yogita Soni', 2019; (9), pp. 72-73.

16. Mallongi, A., Parkpian, P., Pataranawat, P., Chinwetkitvanich, S ., Mercury distribution and its potential environmental and health risks in aquatic habitat at artisanal buladu gold mine in Gorontalo Province, Indonesia, Pakistan Journal of Nutrition Volume 14, Issue 12, 2015, Pages 1010-1025

17. A Mallongi, D Safiu, H Amqaim, A Syam, M Hatta, T Sutarti, A Muhith,. Modelling of S02 and CO Pollution Due to Industry PLTD Emission Tello in Makassar Indonesia. Journal of Engineering and Applied Sciences 14 (2), 634-640
18. Mallongi, A., Daud, A., Ishak, H., La Ane, R., Birawida, A.B., Ibrahim, E., Selomo, M., Rahman, S.A. Clean water treatment technology with an upflow slow sand filtration system from a well water source in the tallo district of Makassar. Journal of Environmental Science and Technology, 2017; Volume 10, Issue 1, Pages 44-48

19. Hasmi, Mallongi, A. Health risk analysis of lead exposure from fish consumption among communities along Youtefa Gulf, Jayapura. Pakistan Journal of Nutrition 2016; Volume 15, Issue 10, 15 September Pages 929-935

20. Kayame, R., Mallongi, A. Relationships between smoking habits and the hypertension occurrence among the adults of communities in paniai regency, Papua Indonesia. Indian Journal of Public Health Research and Development 2018; Volume 9, Issue 1, Pages 332-336

21. Endah Yani, R.W., Mallongi, A., Andarini, S., Prijatmoko, D., Dewanti, I.R. The effect of zinc saliva on the toddlers' nutritional status. Journal of International Dental and Medical Research, 2016, Volume 9, Issue 1, Pages 29-32

22. Birawida, A.B., Selomo, M., Mallongi, A. Potential hazards from hygiene, sanitation and bacterium of refill drinking water at Barrang Lompo island (water and food safety perspective) IOP Conference Series: Earth and Environmental Science 2018; Volume 157, Issue 1, Article number 012034

23. Fitriani, H., R, A. S. And Nurdiana, P. Risk Factors Of Maternal Nutrition Status During Pregnancy To Stunting In Toddlers Aged 12-59 Months, Jurnal Keperawatan Padjadjaran, 2020; 8(2), pp. 183-191. doi: $10.24198 / \mathrm{jkp} . \mathrm{v} 8 \mathrm{i} 2.1305$. 